\title{
A NEW Pycnogonum FROM BRAZIL
}

(Received 4/7/61)

\section{Eveline and Ernst Marcus*}

(with 1 plate)

Pycnogonum gibberum, spec. nov.

Locality - Lage de Santos, about $40 \mathrm{~km} \mathrm{~S}$ off Santos, $32 \mathrm{~m}$.

Material - Holotype: one male numbered 1089 ARACHnoIdea. Paratypes: one female in the collection of the "Departamento de Zoologia da Secretaria da Agricultura" of the State of São Paulo, a second female in the collection of the Oceanographic Institute of the University of São Paulo, dredged by Lic. Luiz Roberto Tommasi, and a third female from Alcatrazes I., $36 \mathrm{~m}$, $10 / 8 / 61$, dredged by the Necton Staff of that Institute.

DESCRIPTION - Trunk compact, completely segmented; lateral processes touching. Three dorsal trunk tubercles taller than eye tubercle and bearing a few bristles. One median small tubercle on fourth segment and one near tip of abdomen. Smaller tubercles on lateral processes and on first and second coxae. Integument heavily reticulated and bearing numerous small warts many of which with setae. Proboscis slightly curved downwards, about two thirds the length of the trunk, tapering from base to tip. Abdomen widened, rounded at the tip.

Oviger 7-jointed, third and fourth joints broader than fifth, but distinctly longer than broad. Terminal claw about two thirds

- Caixa Postal 6994, São Paulo. 
the length of the seventh joint. Measurements (in $\mathrm{mm}$ ) : I 0,2 ; II 0,1 ; III 0,3 ; IV 0,35 ; V 0,35 ; VI 0,3 ; VII 0,25 ; Claw about 0,15 .

Leg thick, knobby; femur shorter than sum of coxae; second tibia distinctly shorter than first; terminal claw less than half as long as propodus.

Measurements in $\mathrm{mm}$ :

length incl. proboscis and abdomen ..

length of trunk

length of segment $I$

length of segment II

length of segments III + IV

breadth of segment I

breadth of segment II

breadth of segment III + IV

maximum breadth of trunk without lateral processes

abdomen

proboscis, dorsal length

proboscis, ventral length

proboscis, basal width

proboscis, width at tip

third leg: coxa 1

coxa 2

coxa 3

femur

tibia 1

tibia 2

tarsus + propodus

claw male

5,2

3,2

1,0

0,4

1,08

2,1

2,2

1,9

1,2

0,9

1,9

2,2

1,0

0,4

0,5

0,6

0,5

1,3

1,2

0,8

0,9

0,38 female 1 female 2

7,2

6,9

3,7

3,5

1,4

1,45

0,62

0,6

1,6

1,5

2,7

2,75

2,2

2,7

1,5

2,2

1,3

1,1

1,1

2,3

2,8

2,5

1,2

0,54

0,54

0,6

0,62

0,8

0,55

0,6

0,6

1,6

1,4

1,4

1,5

0,7

0,8

1,0

1,2

0,42

0,32

Discussion - A closely related species is Pycnogonum reticulatum Hedgpeth (1948, p. 279), first published as Pyconogonum sp. (Hedgpeth 1947, p. 13). The species based on 2 males 
and 3 females was found at Key West; Tortugas, Florida; and El Salvador on the Pacific coast of the Isthmus of Panama. Stock (1954, p. 129) added 2 males from Islote Aves, W of Dominica, Lat. $15^{\circ} 41^{\prime} \mathrm{N}$, Long. $63^{\circ} 40^{\prime} \mathrm{W}$.

P. gibberum differs from reticulatum by higher median and more numerous trunk tubercles. Median processes on the trunk segments exceeding the ocular tubercle in height are rare in reticulated species of Pycnogonum (Schmitt 1934, p. 63). The proboscis of gibberum tapers more from base to tip than that of reticulatum. In gibberum the diameter of the tip is less than half $(40-45 \%)$ that of the base, in the three published figures of reticulatum half or more $(50-54 \%)$ of the basal width. Minor differences between gibberum and reticulatum refer to the breadth of the middle joints of the oviger and to the second tibiae of the females which are half the length of the first or little more.

A shagreened, not reticulated, Pycnogonum from the coast of São Paulo, P. pamphorum Marcus (1940, p. 115) is related with P. cessaci Bouvier (1911, p. 493) from the Cape Verde Islands. Neither its original description nor a short addition (Bouvier 1917, p. 44) informed sufficiently about this not figured species, not mentioned in the Zoological Record for 1911, where the paper is reported, nor in Schimkewitsch's (1929-30) and Helfer \& Schlottke's (1935) monographs.

Fage (1952) re-described the material of Bouvier and studied specimens of cessaci from Dakar. We agree with his separation (p. 532) of pamphorum from cessaci: auxiliary claws (absent in cessaci); eye tubercle at a considerable distance from anterior border of first segment (in cessaci this distance equal to diameter of eye tubercle); a small knob behind the eye tubercle occurs in cessaci, not in pamphorum; and the femoral prominence of cessaci stronger than that of pamphorum. Not mentioned by Fage but evidenced by his text and figure is the cylindrical proboscis of cessaci against the nearly barrel-shaped one of pamphorum.

Stock (1954, p. 129; also in Hoenigman \& Stock 1955, p. 535) does not consider these traits as sufficient for taxonomic separation and so called a male with small auxiliary claws from Los Frailes, N E of Margarita Island (Lat. $11^{\circ} 15^{\prime} \mathrm{N}$, Long. 63'42 W) 
P. cessaci. The other characteres which separate cessaci and pamphorum are not indicated for this specimen.

Fage (p. 531) recognized the identity of $P$. leticiae MelloLeitão $(1945$, p. 1) from Rio de Janeiro with P. cessaci. Three specimens of our collection, from São Vicente near Santos, are leticiae, hence cessaci, now definable as amphiatlantic.

\section{RESUMO}

Pycnogonum gibberum, spec. nov., da Ilha Lage de Santos, $32 \mathrm{~m}$, distingue-se da espécie semelhante, $P$. reticulatum Hedgpeth 1948, pela altura das saliências medianas superior à do tubérculo ocular, gibas dorsais mais numerosas, tromba mais estreita na ponta, e pormenores das dimensões do $3 .^{\circ}$ e $4 .^{\circ}$ artículos do ovigero e das tíbias nas fêmeas.

Pycnogonum cessaci Bouvier 1911 e P. leticiae Mello-Leitão 1945 são idênticos (Fage 1952). P. pamphorum Marcus 1940 difere de cessaci pela presença de unhas auxiliares, ausência de proeminência atrás do tubérculo ocular, tromba quase de forma de tonel, não cilíndrica, e outros caracteres indicados por Fage.

\section{REFERENCES}

BOUVIER, E. L.

1911. Observations sur les Pycnogonomorphes, etc. C. R. Acad. Sci., vol. 152 , p. 491-494.

1917. Pycnogonides provenant des campagnes scientifiques de S. A. S. le Prince de Monaco. Résult. Camp. Scient., fasc. 51, p. 1-56, pl. 1-4.

FAGE, L.

1952. Sur quelques Pycnogonides de Dakar. Bull. Mus. Hist. Nat., sér. 2, vol. 24, n. $^{\circ} 6$, p. 530-533. 1 fig.

HedgPETH, J. W.

1947. On the evolutionary significance of the Pycnogonida. Smithson. Misc. Coll., vol. 106, n. ${ }^{\circ} 18$, p. $1-53,16$ text-figs., 1 pl.

1948. The Pycnogonida of the western North Atlantic and the Caribbean. Proc. U. S. Nat. Mus., vol. 97, n. ${ }^{\circ} 3216$, p. 157-342, 53 text-figs. 1 chart.

Helfer, H. \& Schlottke, E.

1935. Pantopoda in Bronn's Kl. Ordn. Tierr., vol. 5, Abtlg. 4, 2. Buch, viii + 314 p., 233 text-figs. Leipzig, Akadem. Verlagsgs.

Hoenigman, J. \& Stock, J. H.

1955. Das männliche Geschlecht von Pycnogonum pusillum, etc. Entomol. Ber., part 15, p. 534-536, 2 text-figs. 
Marcus, E.

1940. Os Pantopoda brasileiros e os demais sul-americanos. Bol. Fac. Fil. Ciên. Letr. Univ. S. Paulo, vol. 19, Zool. 4, p. 3-144, 17 pls.

Mello-Leitão, A. de

1945. Uma espécie nova do gênero Pycnogonum, etc. Bol. Mus. Nac., n. ser. Zool. n. ${ }^{\circ} 42$, p. 1-4, 7 figs.

Schimkewitsch, W.

1929-30. Faune de l'U.S.S.R. et des pays limitrophes. Pantopodes. Fasc. 1 (1929), cxiv + 224 p., figs. 1-57, pl. 1-4; Fasc. 2 (1930), p. $225-554$, figs. $58-166$, pl. 5-10.

Schmitt, W. L.

1934. Notes on certain pycnogonids including descriptions of two new species of Pycnogonum. Journ. Wash. Acad. Sci., vol. 24, n. ${ }^{\circ} 1$, p. $61-70,2$ text figs.

STock, J.

1954. Four new Tanystylum species, and other Pycnogonida from the West Indies. Stud. Fauna of Curaçao and other Caribbean islands, vol. 5, p. 116-129, text-figs. 24-29. The Hague, Martinus Nijhoff. 


$$
-8-
$$

EXPLANATION OF FIGURES

Fig. 1 - Dorsal view of female.

Fig. 2 - Third leg.

Fig. 3 - Termination of same.

Fig. 4 - Oviger.

Fig. 5 - Lateral view of female. 


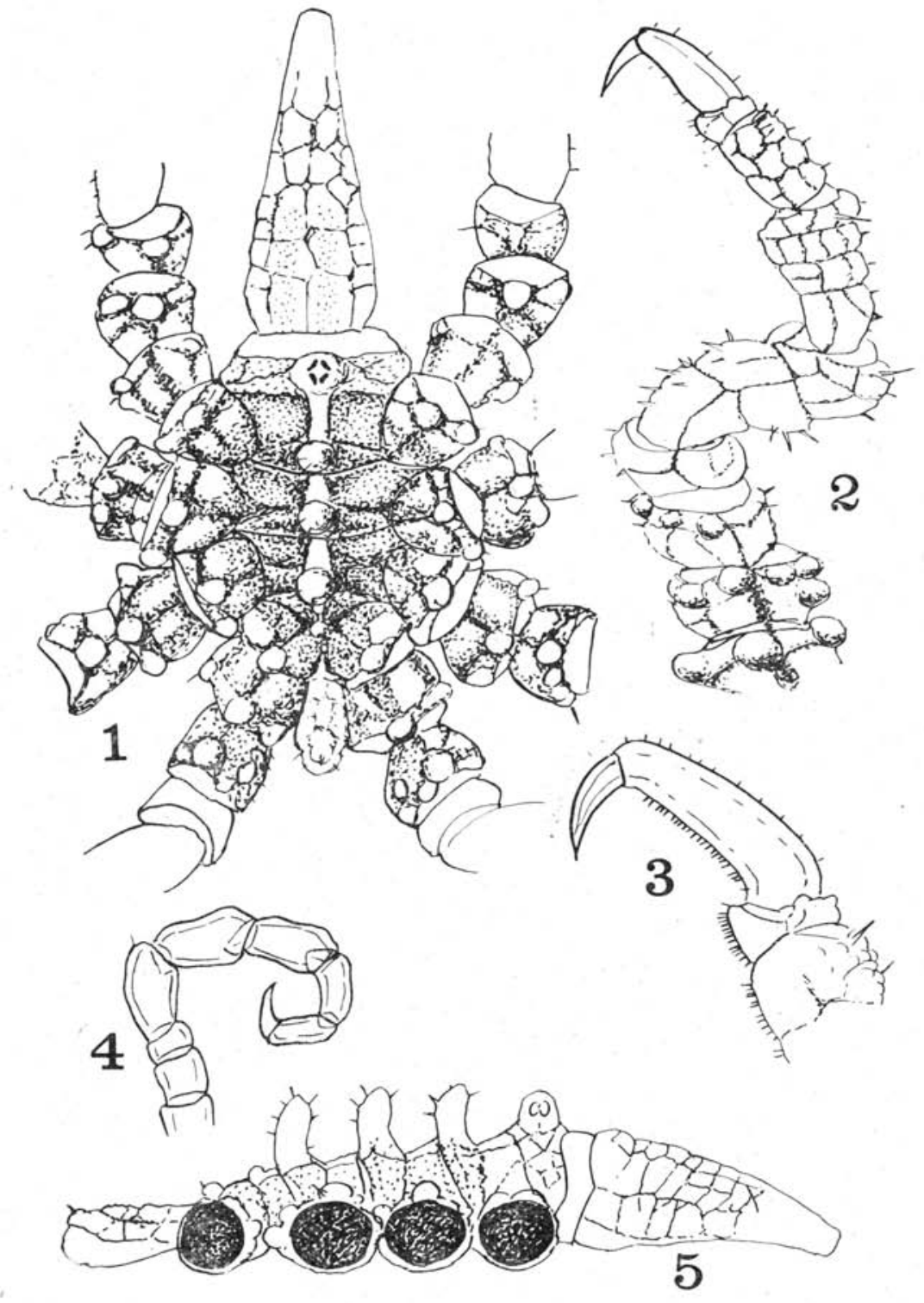

